\title{
PENGARUH PELATIHAN TERHADAP KINERJA KARYAWAN PENGRAJIN SEPATU DAN SANDAL KULIT "PRAKTIS" MAGETAN
}

\author{
Endrawati \\ Pendidikan Ekonomi FKIP UNIVERSITAS PGRI MADIUN \\ endrawati@yahoo.com
}

\begin{abstract}
This study aims to determine the effect of providing job training on the performance of employees home industry "Praktis" Magetan. The research used quantitative descriptive method. The instruments used to collect data are questionnaires or questionnaires. The result of this research indicates that there is a significant positive effect of training variable on employee performance, it is proved by regression analysis result that get $Y=14,340+$ $0,5307 X$, that means if job training variable $(X)$ increase by $1 \%$, hence employee performance Will increase by 0.5307 , if other factors are considered fixed. Test t calculation results obtained $t_{\text {count }}(9,9076) \geq t_{\text {table }}(1.66691)$ This situation can be said there is different influence of training on employee performance on the Shoes and Slippers "Praktis" Magetan Leather Sandal. Thus it can be concluded that the training effect on employee performance.
\end{abstract}

Keywords: Training, Employee Performance

\begin{abstract}
Abstrak
Penelitian ini bertujuan untuk mengetahui pengaruh pemberian pelatihan kerja terhadap kinerja karyawan home industry "Praktis" Magetan. Penelitian menggunakan metode deskriptif kuantitatif. Instrumen yang digunakan untuk mengumpulkan data adalah angket atau kuesioner. Hasil dari penelitian ini menunjukkan bahwa terdapat pengaruh positif signifikan variable pelatihan terhadap kinerja karyawan, hal ini dibuktikan dengan hasil analisis regresi yang memperoleh hasil $\mathrm{Y}=14,340+0,5307 \mathrm{X}$, Artinya jika variabel pelatihan kerja $(\mathrm{X})$ meningkat sebanyak 1\%, maka kinerja karyawan akan meningkat sebesar 0,5307, apabila faktor lain dianggap tetap. Uji t hasil perhitungan diperoleh hasil $t_{\text {hitung }}$ $(9,9076) \geq t_{\text {tabel }}(1,66691)$ Keadaan ini dapat dikatakan ada beda pengaruh pelatihan terhadap kinerja karyawan pada Pengrajin Sepatu dan Sandal Kulit "Praktis" Magetan. Dengan demikian dapat disimpulkan bahwa pelatihan berpengaruh terhadap kinerja karyawan.
\end{abstract}

Kata Kunci: Pelatihan, Kinerja Karyawan 


\section{PENDAHULUAN}

Sumber Daya Manusia (SDM) merupakan aset perusahaan yang paling mahal dibandingkan dengan aset-aset lain karena SDM merupakan penggerak utama organisasi perusahaan. SDM harus dikelola secara optimal, dan diberi perhatian ekstra untuk dipenuhi hak-haknya.

Menurut Abdurrahmat Fathoni (dalam Subekhi dan Jauhar, 2012: 13) “Sumber Daya Manusia merupakan modal dan kekayaan yang terpenting dari setiap kegiatan manusia". Manusia sebagai unsur terpenting mutlak dianalisis dan dikembangkan dengan cara tersebut. Waktu, tenaga dan kemampuannya benar-benar dapat dimanfaatkan secara optimal, bagi kepentingan organisasi, maupun bagi kepentingan individu.

Untuk wewujudkan harapan perusahaan untuk mendapatkan sumber daya manusia yang berkompeten dan berkualitas maka perusahaan mengadakan seleksi yang ketat dalam penerimaan karyawan. Selain mengadakan seleksi, perusahaan juga mengadakan berbagai pelatihan untuk memberikan pengetahuan, keahlian, dan keterampilan bagi karyawan. Hal ini akan menghasilkan sumber daya manusia yang berkualitas. Pelatihan bertujuan untuk meningkatkan pengetahuan, keahlian dan keterampilan karyawan, sehingga karyawan mampu melaksanakan pekerjaan sesuai dengan kebutuhan perusahaan.

Bagi suatu organisasi atau perusahaan, pelatihan merupakan aktivitas yang cukup penting, dimana hal ini diharapkan dapat meningkatkan produktivitas kerja dan prestasi kerja bagi tenaga kerja itu sendiri dan organisasi atau perusahaan dimana tenaga kerja tersebut bekerja.

Menurut Lubis 2008 (dalam Leonando dan Eddy, 2013:2 ) "melalui pelatihan dan motivasi akan berpengaruh pada peningkatan kinerja karyawan. Dengan motivasi yang kuat serta pelatihan yang maksimal diharapkan kinerja yang dihasilkan karyawan dapat meningkat sehingga tujuan atau harapan perusahaan dapat tercapai”.

Menurut (Danang Sunyoto, 2013:140) tujuan utama pelatihan yaitu : (a) Memperbaiki kinerja, (b) Mengurangi waktu belajar (c) Membantu memecahkan masalah operasional (d) Promosi karyawan (e) Mengorientasikan karyawan terhadap organisasi (f) Memenuhi kebutuhankebutuhan pribadi.

Sedangkan menurut (Windy Aprilia, 2012:217) "Kinerja karyawan merupakan suatu hal yang sangat penting dalam suatu organisasi untuk mencapai tujuannya, sehingga berbagai kebijakan harus dilakukan organisasi untuk meningkatkan kinerja karyawannya".

Kinerja dapat diketahui dan diukur jika individu atau sekelompok karyawan telah mempunyai kriteria atau standar keberhasilan tolok ukur yang ditetapkan oleh organisasi. Oleh karena itu, jika tanpa tujuan dan target yang ditetapkan dalam pengukuran, maka kinerja pada seseorang atau kinerja organisasi tidak mungkin dapat diketahui bila tidak ada tolok ukur keberhasilannya.

Berdasarkan pada teori Mathis dalam (Deni primajaya, 2006:12) yang mengatakan ada tiga faktor utama yang mempengaruhi kinerja, (1) kemampuan meliputi: bakat, minat, factor kepribadian, (2) usaha yang dicurahkan meliputi: motivasi, etika kerja, kehadiran, rancangan tugas, (3) dukungan organisasi meliputi: pelatihan dan pengembangan, peralatan dan teknologi, standar kinerja, serta manajemen dan rekan kerja.

Dengan mengikuti pelatihan diharapkan karyawan dapat meningkatkan kinerja karyawan dalam suatu perusahaan. Dengan demikian kelangsungan atau kelancaran perusahaan dapat berproduksi dan berkembang sesuai dengan yang diharapkan.

Biasanya perusahaan-perusahaan menyadari betapa pentingnya kinerja 
karyawan untuk bekerja lebih baik dan penuh rasa tanggung jawab dalam menjalankan tugasnya dari pimpinan suatu perusahaan.

Dengan demikian perusahaan tersebut dapat menghasilkan karyawan terampil dan berkualitas yang diharapkan dapat menunjang pencapaian tujuan perusahaan dengan hasil yang optimal.

\section{METODOLOGI PENELITIAN}

Desain penelitian yang digunakan menggunakan desain penelitian konklusif.

Menurut Juliansyah Noor (2013 : 110), "penelitian konklusif merupakan penelitian yang bertujuan untuk menguji hipotesis". Penelitian konklusif didesain untuk membantu pengambil keputusan dalam menentukan, mengevaluasi dan memilih alternatif terbaik dalam memecahkan suatu masalah. Jadi dalam riset dengan desain ini mempunyai tujuan untuk menguji hipotesis dan menguji hubungan, dan hasil dari penelitian ini berupa temuan yang digunakan sebagai masukan bagi pembuat keputusan manajemen. Dalam penelitian ini variabel independent atau bebas (X) adalah Pelatihan. Variabel dependen atau terikat (Y) adalah Kinerja Karyawan.

Dalam penelitian ini yang menjadi sampel penelitian adalah semua karyawan "Praktis" Magetan yang seluruhnya berjumlah 35 karyawan. Metode pengumpulan data menggunakan kuesioner dengan menggunakan skala likert. Jumlah soal yang dibagi dalam 2 variabel, dengan perincian untuk variabel Pelatihan 10 soal dan variabel Kinerja Karyawan 10 soal.

\section{HASIL PENELITIAN}

\section{Variabel Pelatihan}

Deskripsi dari variabel pelatihan, dengan jumlah data $(\mathrm{N})$ sebanyak 35 orang memiliki deskripsi data sebagai berikut : (a) Jumlah skor total sebesar 1061: (b) Nilai rata-rata hitung (mean) sebesar 30.31: (c) median sebesar 30.00: (d) modus sebesar 30: (e) standart deviasi sebesar 4,735 (f) nilai minimum sebesar 18: (g) nilai maximum sebesar 40.

Dari hasil analisis pelatihan diatas dapat diketahui hasil analisis kuesioner dari 35 karyawan yang berada diatas rata-rata $\geq 30,31$ sebanyak 45,7\% (16 orang) sedangkan yang mendapat skor dibawah rata-rata $\leq 30,31$ sebanyak 54,3\% (19 orang). Artinya 16 orang menyatakan setuju apabila diadakan pelatihan kerja untuk karyawan.

\section{Variabel Kinerja Karyawan}

Deskripsi dari variabel kinerja karyawan, dengan jumlah data $(\mathrm{N})$ sebanyak 35 orang memiliki deskripsi data sebagai berikut: (a) jumlah skor total sebesar 1065 (b) Nilai rata-rata hitung (mean) 30.43, (c) Median 30.00, (d) Modus 29, (e) Standar Deviasi 5.376, (f) Nilai Minimum 20 (g) Nilai Maksimum 39.

Dari hasil analisis deskripsi kinerja karyawan diatas dapat diketahui hasil kuesioner dari 35 karyawan yang berada diatas rata-rata $\geq 30.43$ sebanyak $45.8 \%$ (16 orang) dan yang mendapat skor dibawah rata-rata $\leq 30.43$ sebanyak $54.2 \%$. 45.8\% (16 orang) kinerja baik, sedangkan 54.2\% (19 orang) kinerja kurang baik.

\section{Hasil Pengujian Hipotesis}

Hasil Uji Validitas menunjukkan bahwa semua item soal tersebut valid. Item soal dinyatakan valid karena nilai $r_{\text {hitung }} \geq r_{\text {tabel }}$ pada taraf signifikansi 0,05 yaitu 0,334 . Oleh karena itu semua item soal untuk instrumen variabel Pelatihan dan instrumen variabel Kinerja dapat dipercaya.

Hasil Uji Reliabilitas Pelatihan dan Kinerja. Uji Reliabilitas dilakukan dengan rumus Cronbach's Apha. Dalam uji reliabilitas yang dilihat bukan nilai koefisien reliabilitasnya, akan tetapi nilai Cronbach's Alpha.

Data dari penelitian di dapat hasil uji 
reliabilitas terhadap angket pelatihan dan kinerja diperoleh nilai Cronbach's Alpha masing-masing sebesar 0,758 dan 0,781. Karena nilai Cronbach's Alpha 0,70, sehingga dapat disimpulkan bahwa data yang dikumpulkan melalui angket pelatihan dan kinerja karyawan dapat diterima dan reliabel (dipercaya). Oleh karena itu angket pelatihan dan kinerja karyawan dapat digunakan sebagai alat pengumpulan data dalam penelitian.

Pengujian hipotesis dalam penelitian adalah pengujian untuk mencari hubungan sekaligus pengaruh antara variabel pelatihan dan variabel kinerja karyawan.

\section{Uji Kolerasi}

Uji kolerasi digunakan untuk mencari keeratan hubungan antara pelatihan terhadap Kinerja Karyawan.

Hasil uji diperoleh bahwa besarnya nilai $r_{\text {hitung }}$ adalah 0,460 sedangkan $r_{\text {tabel }} 0,334$. Hal ini berarti bahwa nilai $r_{\text {hitung }} \geq r_{\text {tabel }}$ $(0,460 \geq 0,334)$. Dengan demikian tolak Ho, artinya ada hubungan yang signifikan antara pelatihan terhadap kinerja karyawan pengrajin sepatu dan sandal kulit "praktis" Magetan.

Dilain pihak dalam uji determinasi yang diperoleh nilai $\mathrm{R}^{2}$ ( $\mathrm{R}$ Square) atau koefisien determinasi yang digunakan untuk mengetahui seberapa besar prosentase sumbangan pelatihan terhadap kinerja karyawan. Berdasarkan hasil analisis diatas dapat diketahui nilai $\mathrm{R}^{2}$ adalah 0,219 . Jadi sumbangan pengaruh dari pelatihan terhadap kinerja karyawan yaitu 21,9\% sedangkan sisanya sebesar 78,1\% dipengaruhi oleh faktor lain.

\section{Uji F/Uji Fisher}

Uji F digunakan untuk menguji pengaruh pelatihan terhadap kinerja karyawan.

Hasil uji diperoleh bahwa besarnya nilai $F_{\text {hitung }}$ adalah 33,062 sedangkan sebesar
$F_{\text {tabel }} 3,28$, dilain pihak besarnya $S_{i g}$ adalah 0,000 sedangkan $\mathrm{Sig}_{\text {pro }}$ 0,05. Hal ini berarti bahwa nilai $F_{\text {hitung }} \geq F_{\text {tabel }}(33,062 \geq 3,28$ atau $\mathrm{Sig}_{\text {hit }} \leq \operatorname{Sig}_{\text {pro }}(0,000 \leq 0,05)$. Dengan demikian tolak Ho, artinya ada pengaruh secara keseluruhan antara pelatihan terhadap kinerja karyawan pengrajin sandal dan sepatu kulit "praktis" Magetan.

\section{Uji t/ Uji Beda Pengaruh}

Uji t digunakan untuk mencari beda pengaruh antara pelatihan terhadap kinerja karyawan.

Atas dasar data yang diolah diperoleh persamaan garis regresi sebagai berikut: $\mathrm{Y}=14,340+0,5307 \mathrm{X}$. Artinya apabila pelatihan meningkat sebanyak $1 \%$, maka kinerja karyawan akan meningkat sebesar 0,5307, apabila faktor lain dianggap tetap.

Selanjutnya diketahui bahwa $t_{\text {hitung }}$ adalah 2,97 sedangkan $t_{\text {tabel }} 1,66691$, dilain pihak nilai $\mathrm{Sig}_{\text {hit }}$ adalah 0,000 sedangkan $\mathrm{Sig}_{\text {pro }}$ 0,05. Hal ini berarti bahwa nilai $t_{\text {hitung }} \geq t_{\text {tabel }}(2,97 \geq$ $1,66691)$ atau $\operatorname{Sig}_{\text {hit }} \leq \operatorname{Sig}_{\text {pro }}(0,000 \leq 0,05)$. Atas dasar uji t tersebut dapat disimpulkan tolak Ho, artinya ada beda pengaruh antara pelatihan terhadap kinerja karyawan pengrajin sandal dan sepatu kulit "praktis" Magetan

\section{HASIL DAN PEMBAHASAN}

Hasil penelitian menunjukkan bahwa pelatihan mempunyai pengaruh positif signifikan terhadap kinerja karyawan. Hal ini menunjukkan bahwa karyawan yang mendapatkan pelatihan cukup akan memiliki kinerja yang lebih baik.

Koefisien deteminasi yang diperoleh pada penelitian ini sebesar 0,219 (21,9\%), sehingga dapat dikatakan pelatihan memiliki pengaruh $23 \%$ dalam menunjang kinerja karyawan, sedangkan sisanya sebanyak 78,1 $\%$ dipengaruhi faktor lain. Nilai Adjusted 
yang ditunjukkan dalam analisis hasil penelitian ini membuktikan bahwa pelatihan mempengaruhi kinerja karyawannya.

Dilain pihak dalam uji hipotesis dengan regresi yang didalamnya memuat uji kolerasi, uji $\mathrm{F}$ dan uji t, dalam pembahasannya adalah sebagai berikut.

\section{Pembahasan Uji Kolerasi}

Dalam uji kolerasi dapat diketahui besarnya nilai $r_{\text {hitung }}$ adalah 0,460 sedangkan $r_{\text {tabel }} 0,334$. Hal ini berarti bahwa nilai $r_{\text {hitung }} \geq r_{\text {tabel }}(0,460 \geq 0,334)$, atau dapat disimpulkan bahwa Ho ditolak, artinya ada hubungan yang signifikan antara pelatihan terhadap kinerja karyawan pengrajin sandal dan sepatu kulit "Praktis" Magetan.

\section{Pembahasan Uji F}

Dari analisis data yang telah dilakukan untuk uji Fisher dengan ANOVA diperoleh hasil nilai nilai $F_{\text {hitung }}$ adalah 33,062 sedangkan $F_{\text {tabel }}$ sebesar 3,28, dilain pihak besarnya $\mathrm{Sig}_{\text {hit }}$ adalah 0,000 sedangkan $\mathrm{Sig}_{\text {pro }}$ 0,05. Hal ini berarti bahwa nilai $F_{\text {hitung }} \geq F_{\text {tabel }}$ $(194,802 \geq 3,963)$ atau Sig $_{h i t} \leq$ Sig $_{\text {pro }}$ $(0,000 \leq 0,05)$, atau dapat disimpulkan bahwa Ho ditolak, artinya ada pengaruh secara keseluruhan antara pelatihan terhadap kinerja karyawan pengrajin sandal dan sepatu kulit "praktis" Magetan

\section{Pembahasan Ujit}

Dari hasil analisis dapat dibuat persamaan garis regresi sebagai berikut $\mathrm{Y}=$ $14,340+0,5307 \mathrm{X}$, artinya adalah apabila pelatihan ditingkatkan $1 \%$ maka kinerja karyawan akan naik $0,5307 \%$ apabila faktor lain tetap.

Berdasarkan analisis diatas dapat diketahui bahwa $t_{\text {hitung }}$ adalah 2,97 $t_{\text {tabel }}$ adalah 1,66691, dilain pihak nilai Sig $_{\text {hit }}$ adalah 0,000 sedangkan Sig $_{\text {pro }}$ 0,05. Hal ini berarti bahwa nilai $t_{\text {hitung }} \geq t_{\text {tabel }}(2,97 \geq 1,66691)$ atau Sig $_{\text {hit }} \leq$
$\operatorname{Sig}_{\text {pro }}(0,000 \leq 0,05)$, atau dapat disimpulkan bahwa Ho ditolak, artinya ada beda pengaruh antara pelatihan terhadap kinerja karyawan pengrajin sepatu dan sandal "praktis" Magetan.

Berdasarkan hasil penelitian menunjukkan bahwa pelatihan mempunyai pengaruh terhadap kinerja karyawan. Hal ini menunjukkan bahwa bahwa karyawan yang mendapatkan pelatihan secara cukup akan memiliki kinerja yang lebih baik dalam bekerja.

Pengaruh tersebut menandakan bahwa semakin tercukupi pelatihan kerja maka akan semakin baik pula kinerja karyawan, sebaliknya semakin kurang pelatihan maka akan semakin rendah pula tingkat kinerja karyawan.

\section{PENUTUP \\ Simpulan}

Berdasarkan dari hasil penelitian, yang kemudian dilakukan penghitungan, analisis dan pembahasan terhadap data-data yang diperoleh, maka dapat diambil kesimpulan sebagai berikut:

1. Pelatihan marupakan kegiatan untuk meningkatkan pengetahuan, kemampuan, keterampilan dan perubahan sikap individu dalam perusahaan agar dalam melaksanakan tugas yang diembannya menjadi lebih baik lagi, dengan kata lain setiap pegawai membutuhkan suatu pelatihan untuk meningkatkan kompetensi dirinya. Pelatihan akan menimbulkan perubahan dalam kebiasaan bekerja, perubahan sikap, tingkah laku, keterampilan serta pengetahuan karyawan. dan pelatihan tersebut harus dilakukan secara terus menerus agar dapat menyesuaikan dengan perkembangan ilmu pengetahuan dewasa ini. Pelatihan merupakan proses timbal balik yang bersifat membantu dan mereka yang dilatih harus aktif demi keberhasilan pelatihan dalam meningkat- 
kan mutu sumber daya manusia dalam lingkungan perusahaan.

2. Kinerja karyawan merupakan salah satu aspek penentu dalam pencapaian tujuan dalam suatu organisasi atau perusahaan. Kinerja karyawan juga dikatakan sebagai penggerak sistem manajemen yang ada di dalam perusahaan guna menjalankan aktifitas-aktifitas yang sudah direncanakan. Penilaian kinerja karyawan dapat dilihat dari Quality of work : kualitas kerja yang dicapai berdasarkan syarat-syarat kesesuaian dan kesiapan, Job knowledge: luasnya pengetahuan mengenai pekerjaan dan ketermpilan, Cooperation: kesediaan untuk bekerjasama dengan orang lain/sesama anggota organisasi, Initiative: semangat untuk melaksanakan tugas-tugas baru dan dalam memperbesar tanggung jawabnya dan Dependability: kesadaran untuk dapat dipercaya dalam hal kehadiran dan penyelesaian kerja.

3. Pelatihan memiliki pengaruh positif signifikan terhadap kinerja karyawan. Hal ini ditunjukkan dari hasil penelitaian yang telah dilakukan. Pelatihan memiliki pengaruh sebesar $21,9 \%$ terhadap peneliti. sedangkan sisanya $78,1 \%$ dipengaruhi oleh faktor lain yang tidak diteliti. Hal ini menunjukkan bahwa semakin cukup pelatihan yang diberikan kepada karyawan, maka kinerja karyawan anak semakin baik.

\section{Saran}

Berdasarkan kesimpulan diatas, maka dapat dikemukaan beberapa saran yang bermanfaat sebagai berikut:

1. Sebagai karyawan harus mampu meningkatkan lagi kinerja yang diberikan kepada perusahaan sebagai wujud tanggung jawab dan dedikasinya terhadap perusahaan.

2. Perusahaan diharapkan memberikan jumlah pelatihan kerja sehingga mampu meningkatkan kinerja karyawan.
3. Diharapkan peneliti yang lain mampu melakukan penelitian yang lebih baik lagi dengan menguji berbagai variable lain yang terkait dengan kinerja karyawan yang tidak diteliti dalam penelitian kali ini.

\section{DAFTAR PUSTAKA}

Akhmad, Subheki dan Jauhar. 2012. Pengantar manajemen SDM, Jakarta: Pustaka Raya.

Anwar, Prabu. 2013. Manajemen SDM Perusahaan. Bandung: Remaja Rosdakarya.

Anwar, Prabu. 2005. Evaluasi Kinerja SDM, Bandung: Refika Aditama

Deny, Primajaya. Pengaruh Motivasi Kerja dan Pelatihan Kerja Terhadap Kinerja Karyawan Pada PT Pertamina (persero) UPMSIV Semarang.

Hamid, Darmadi. 2011. Metodologi Penelitian Pendidikan. Bandung: Alfabeta.

Danang, Sunyoto. 2013. Manajemen SDM. Yogyakarta, CAPS

Jackson, Schuler. Werner. 2011. Pengelolaan SDM, Jakarta: Salemba Empat.

Moh, As’ad. 2012 Seri Ilmu SDM, Psikologi Industri. Yogyakarta: Liberty.

Moeheriono. 2010. Pengukuran Kinerja Berbasis Kompetensi. Bogor: Ghalia Indonesia.

Ambar Teguh. S, Rosidah. 2003. Menejemen SDM. Yogyakarta: Graha Ilmu.

Veithzal, Rival. 2009 Manajemen SDM Untuk Perusahaan. Jakarta: Raja Grafindo Persada.

Sugiyono. 2010. Metodologi Penelitian Pendidikan. Jakarta: Alfabet. 
Sugiyono. 2007. Statistika untuk penelitian. Bandung :Alfabeta

Supardi. 2005. Metodelogi Penelitian Ekonomi Bisnis. Yogyakarta: UII Press

Sofyan Siregar. 2012. Statistika Parametrik Untuk Penelitian Kuantitatif. Jakarta: Bumi Aksara.

Imam Ghozali. 2013. Aplikasi Analisis Multivariate Dengan Program IBM SPSS 21. Semarang: Badan Penerbit Universitas Diponegoro.
Margono. 2010. Metodelogi Penelitian Pendidikan. Jakarta: Rineka Cipta.

Leonando dan Eddy. 2013. Pengaruh Pelatihan dan Motivasi Kerja Terhadap Kinerja Karyawan CV Haragon Surabaya

Ma'aruf Abdullah. 2014. Manajemen dan Evaluasi Kinerja Karyawan. Yogyakarta: Aswaja Pressindo

Willson Bangun. 2012. Manajemen SDM. Jakarta: Erlangga

Edy, Sutrisno. 2010. Budaya Organisasi. Jakarta: Kencana 